\title{
Changes in food web structure under the influence of increased anthropogenic nitrogen inputs to estuaries
}

\author{
James W. McClelland*, I. Valiela \\ Boston University Marine Program, Marine Biological Laboratory, Woods Hole, Massachusetts 02543, USA
}

\begin{abstract}
Anthropogenic nitrogen loads to shallow coastal waters have been linked to shifts from seagrass- to algae-dominated communities in many regions of the world, yet the influence that these shifts have on the structure of nearshore food webs remains unclear. We used stable $\mathrm{C}$ and $\mathrm{N}$ isotope ratios to assess the relative importance of phytoplankton, macroalgae, and eelgrass Zostera marina as food sources to consumers in estuaries of Waquoit Bay, Massachusetts, USA, that receive low versus high nitrogen loads from their surrounding watersheds. We found that, in general, the diets of herbivores, suspension feeders, and detritivores (collectively referred to as primary consumers) in the Waquoit Bay estuaries are influenced by the dominant forms of production that they are exposed to. Phytoplankton and macroalgae are the major food sources of primary consumers under both low and high $\mathrm{N}$ loading conditions, but eelgrass is also an important food source where $\mathrm{N}$ loading is low. Most of the primary consumers at the estuary with low $N$ loading have between 10 and $16 \%$ eelgrass in their diets. Some species, however, appear to have no eelgrass in their diets, whlle others have diets consisting of as much as $31 \%$ eelgrass. Eelgrass $\mathrm{C}$ and $\mathrm{N}$ are passed on to benthic as well as pelagic secondary consumers. With losses of eelgrass as a consequence of nitrogen loading, an important pathway through which land-derived nitrogen enters food webs in the Waquoit Bay estuaries is eliminated. This fundamental change probably affects the rate at which land-derived nitrogen is cycled within estuaries, as well as its ultimate fate.
\end{abstract}

KEY WORDS: Nitrogen loading · Estuaries · Food webs · Coastal watersheds · Urbanization

\section{INTRODUCTION}

Anthropogenic nutrient loads from coastal watersheds to nearshore waters are dramatically altering aquatic habitats (GESAMP 1990, National Research Council 1994). In estuarine and coastal marine waters, increased nitrogen loads stimulate eutrophication (Kelly \& Levin 1986, Nixon 1986, Galloway et al. 1995). As a consequence, the assemblage of primary producers found in these waters often changes (Orth \& Moore 1983, Sand-Jensen \& Borum 1991, Costa et al. 1992, Duarte 1995, Short \& Burdick 1996, Valiela et al. 1997a).

\footnotetext{
·E-mail: jmccle@bio.bu.edu
}

In some shallow temperate waters, eelgrass Zostera marina dominates production under oligotrophic conditions, but is replaced by proliferations of phytoplankton and macroalgae as eutrophication progresses. This shift occurs because eelgrass production is light-limited, whereas phytoplankton and macroalgal production are nutrient-limited (Duarte 1995). Increased nitrogen availability promotes algal growth, and as a result, eelgrass is lost due to shading (Valiela et al. 1997a). A. well-studied example of this phenomenon comes from the Waquoit Bay system on Cape Cod, Massachusetts, USA (Fig. 1). In the 1950s eelgrass grew throughout Waquoit Bay and the estuaries adjoining it (Valiela et al. 1992). Over the past 40 yr, however, nitrogen loading has increased phytoplankton and macroalgal production, causing eelgrass production to decrease as a secondary effect (Valiela et al. 1997a). 


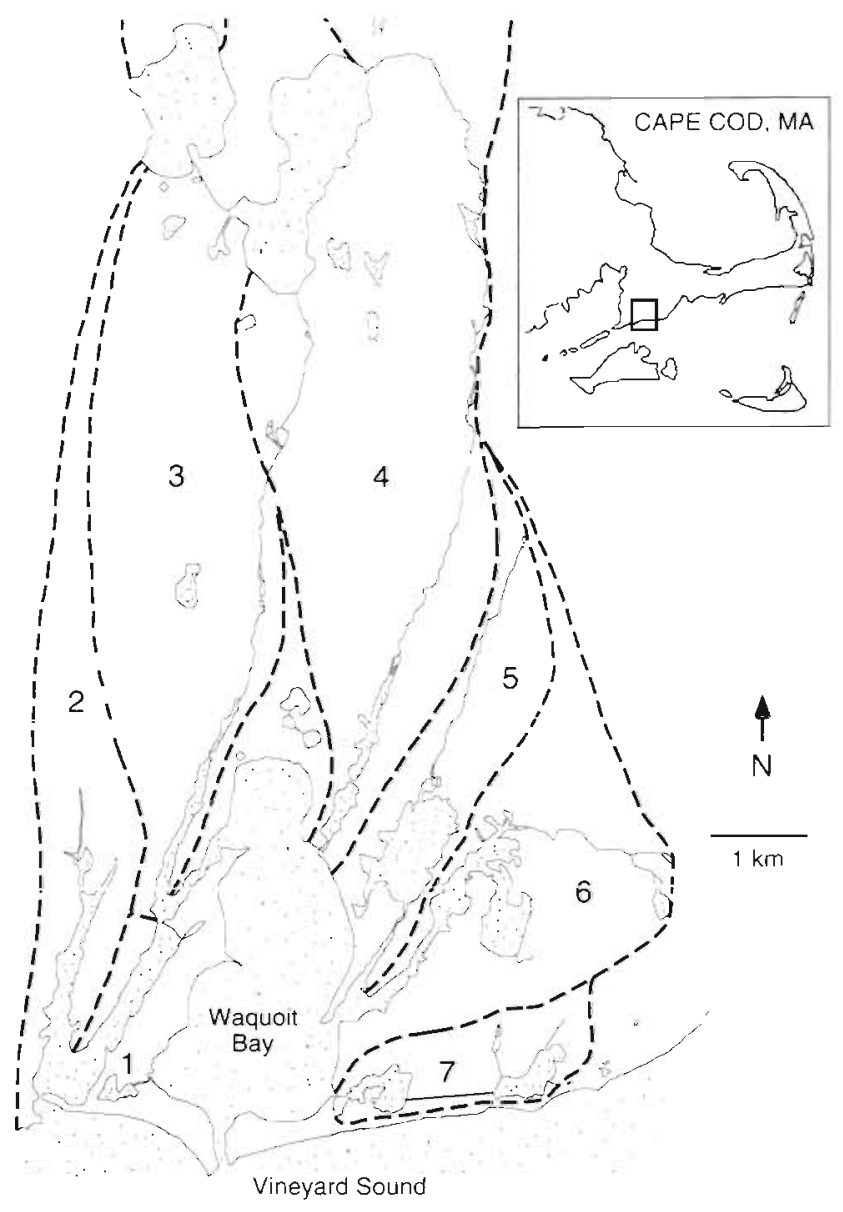

Fig. 1 The Waquoit Bay watershed-estuary system, Cape Cod, Massachusetts, USA. Dashed lines separate the Waquoit Bay watershed into catchment basins associated with different estuaries surrounding Waquoit Bay. Each catchment basin is named for the estuary that it empties into: $1=$ Timms Pond, 2 =Eel Pond, 3 = Childs River, 4 = Quashnet River $5=$ Hamblin Pond, $6=$ Jehu Pond, $7=$ Sage Lot Pond studied receive relatively low (Sage Lot Pond), high (Quashnet River), and higher (Childs River) nitrogen loads (Table 1). In Sage Lot Pond, eelgrass is an important source of production, but at Quashnet River and Childs River, production is dominated by macroalgae (Table 1). By making comparisons among estuaries within the Waquoit Bay system, we gain a better understanding of changes that take place in estuaries as urbanization of coastal watersheds increases. This approach is referred to as a space-for-time substitution (Pickett 1991). Of course, many factors are not controlled in a quasi-experiment such as this, adding some uncertainty to data interpretation. Working at the scale of whole watersheds, however, reveals novel information about ecosystem function that cannot be learned by working at smaller scales. Hence, the added uncertainty inherent to interpretation of data from cross-system comparisons is outweighed by the scalc-spccific information gained with this approach.

Although it is clear that primary producer assemblages change in response to nutrient loading, the influence of such changes on the structure of estuarime fond wehs is poorly understood. If all producers were equally edible (and accessible), then consumers would simply eat them in proportion to their production, and the diets of consumers would change as the mix of producers changed. In fact, however, differences in chemical composition and morphological characteristics among producers make them differ in edibility (Cebrián \& Duarte 1994). For example, nutrient-poor structural tissues in eelgrass make it less desirable as a food source than phytoplankton and macroalgae. Edioility also varies widely among macroalgal species (Nicotri 1980. Heckscher et al. 1996). These differences in edibility make it difficult to predict how and to what extent nutrient-loading-induced changes in primary producer assemblages in coastal waters affect food web structure.
The Waquoit Bay system consists of 7 shallow estuaries (maximum depth of $3 \mathrm{~m}$, and average depth of $1 \mathrm{~m}$ at mean low water) that receive freshwater inputs from separate catchment basins within the Waquoit Bay watershed (Fig. 1). Freshwater enters the estuaries almost exclusively via groundwater flow, and with it landderived nitrogen is conveyed to the estuaries (Valiela et al. 1992). The nitrogen loads delivered to each estuary differ according to land use on the surrounding watershed (Valiela et al. $1997 \mathrm{~b}$ ). The 3 estuaries of Waquoit Bay that have been most extensively
Table 1. Nitrogen loads to the Sage Lot Pond, Quashnet River, and Childs River estuaries of Waquoit Bay, and percentages of primary production contributed by phytoplankton, macroalgae, and eelgrass within these estuaries. N-loading and percentage primary production estimates are based on Waquoit Bay Land Margin Ecosystems Research (WBLMER) measurements (D'Avanzo et al. 1996, Peckol \& Rivers 1996. WBLMER unpubl. data)

\begin{tabular}{|c|c|c|c|}
\hline & Sage Lot Pond & $\begin{array}{c}\text { Estuary } \\
\text { Quashnet River }\end{array}$ & Childs River \\
\hline 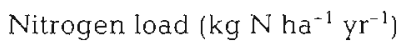 & 64 & 520 & 624 \\
\hline \multicolumn{4}{|l|}{$\%$ of primary production by: } \\
\hline Phytoplankton & 26 & 12 & 26 \\
\hline \multicolumn{4}{|l|}{ Macroalgae } \\
\hline Cladophora vagabunda & 19 & 49 & 56 \\
\hline Gracilaria tikvahiae & 19 & 39 & 17 \\
\hline \multicolumn{4}{|l|}{ Eelgrass } \\
\hline Zostera marina & 37 & $<1$ & $<1$ \\
\hline
\end{tabular}


An effective means to elucidate food web structure is to examine the stable carbon and nitrogen isotope ratios (expressed as $\delta^{13} \mathrm{C}$ and $\delta^{15} \mathrm{~N}$ ) of producers and consumers within a community (for reviews see Fry \& Sherr 1984, Peterson \& Fry 1987, and Lajtha \& Michener 1994). This is because different producers often have unique stable isotope ratios that make them identifiable in mixes of particulate organic matter (Haines 1977, Gearing 1988, Canuel et al. 1995) and in the tissues of consumers (Zieman et al. 1984, Peterson et al. 1985, Fry 1991).

Use of $\delta^{13} \mathrm{C}$ and $\delta^{15} \mathrm{~N}$ in food web studies relies on the assumption that the isotopic composition of a consumer (or mixture of particulate organic matter) is equal to the weighted average of the isotopic compositions of its food sources (Gannes et al. 1997). For example, if an amphipod eats 2 food sources in equal proportions, it is expected to have a $\delta^{13} \mathrm{C}$ value (whole body) that is intermediate to those of the 2 food sources. Where there are multiple food sources, plots of $\delta^{13} \mathrm{C}$ versus $\delta^{15} \mathrm{~N}$ provide a 2-dimensional view of the diets of consumers. As carbon and nitrogen from producers are passed from one trophic level to the next, their $\delta^{13} \mathrm{C}$ and $\delta^{15} \mathrm{~N}$ values tend to increase due to differential use of heavy and light isotopes during metabolism (Fry \& Sherr 1984, Peterson \& Fry 1987, Lajtha \& Michener 1994). There is also a growing body of evidence that stable isotope ratios can change during decomposition (Benner et al. 1987, Curin et al. 1995). These factors must be considered in order to clearly interpret stable isotope data in food web studies.

Previously published nitrogen stable isotope data from the Waquoit Bay system (McClelland et al. 1997) shows that differences in $\delta^{15} \mathrm{~N}$ values of biota among the estuaries of Waquoit Bay are strongly correlated with differences in nitrogen loading from wastewater. As the percentage of wastewater contributing to total $\mathrm{N}$ loading increases among estuaries, the $\delta^{15} \mathrm{~N}$ values of estuarine biota increase. A second paper (McClelland \& Valiela in press) defines the relationship between wastewater inputs to watersheds and the $\delta^{15} \mathrm{~N}$ of dissolved inorganic nitrogen (DIN) in groundwater, and explicitly links groundwater $\delta^{15} \mathrm{~N}$ with producer $\delta^{15} \mathrm{~N}$ in the different estuaries of Waquoit Bay. The $\delta^{15} \mathrm{~N}$ values of groundwater nitrate within the Waquoit Bay watershed increase from -0.9 to $+14 \%$ as wastewater contributions increase from $4 \%$ to $86 \%$ of the total nitrogen pool. As a result, the average $\delta^{15} \mathrm{~N}$ of DIN (nitrate + ammonium) received by different estuaries around Waquoit Bay increases from $+0.5 \%$ to $+9.5 \%$. This increase is paralleled by the $\delta^{15} \mathrm{~N}$ of eelgrass, while macroalgae, salt-marsh cordgrass, and suspended particulate organic matter increase to a lesser degree among estuaries.
In this paper, we use stable $\mathrm{C}$ and $\mathrm{N}$ isotope ratios together to investigate how changes in primary producer assemblages brought about by increased wastewater $\mathrm{N}$ loads influence the diets of consumers in Waquoit Bay. In particular, we assess the relative importance of phytoplankton, macroalgae, and eelgrass as food sources to the consumers. We focus our work on the Sage Lot Pond, Quashnet River, and Childs River estuaries, addressing 3 main questions: (1) What are major primary producers contributing to particulate organic matter (POM) in each estuary? (2) What are the major food sources of consumers in estuaries with low versus high $\mathrm{N}$ loads? (3) How do pathways of $\mathrm{C}$ and $\mathrm{N}$ flow through estuarine food webs change as eutrophication intensifies?

\section{METHODS}

Sample collection. Biota and POM in Sage Lot Pond, Quashnet River, and Childs River were sampled for stable isotope analysis in November 1993, July 1994, May 1995, July 1995, and June 1996. These dates were chosen to cover spring, summer, and fall conditions within the estuaries, and to allow an interannual comparison within the summer season. Samples were not collected during winter months because of low animal abundance. Samples were collected from regions within each estuary characterized by a vertically mixed water column with salinity between 25 and 30 PSU. Producers (except phytoplankton, see below) and POM were sampled from all 3 estuaries, and consumers were sampled from Sage Lot Pond and Childs River.

We could not use suspended POM as a proxy for phytoplankton isotope values - as is often done in open ocean waters-because suspended POM in the estuaries of Waquoit Bay has a large non-phytoplankton (mainly detritus and amorphous organic aggregates) component. However, dense populations of phytoplankton with minimal detrital and aggregate particles were available from the 'controls' of an ongoing experiment on nutrient limitation of phytoplankton in Childs River (Tomasky \& Valiela 1995). We measured the C and N stable isotope values of these 'controls'. Samples were collected for isotope analysis after a July 1996 run of the experiment. Based on the fact that the $\delta^{13} \mathrm{C}$ values of other primary producers within the Waquoit Bay system differed little among estuaries (data presented in this paper), we estimated the $\delta^{13} \mathrm{C}$ of phytoplankton in Quashnet River and Sage Lot Pond to be the same as phytoplankton in Childs River. Similarly, based on consistent differences in macroalgae $\delta^{15} \mathrm{~N}$ among estuaries (McClelland et al. 1997, McClelland \& Valiela in press, and data presented in this 
paper) we estimated the $\delta^{15} \mathrm{~N}$ of phytoplankton in Quashnet River by subtracting 1\%o from the Childs River value, and we estimated the $\delta^{15} \mathrm{~N}$ of phytoplankton at Sage Lot Pond by subtracting $2 \%$ from the Childs River value.

Other producers and consumers were sampled as follows: Suspended POM was sampled by collecting 21 bottles of sea water from a depth of $0.5 \mathrm{~m}$ below the surface at 3 locations within each estuary. Benthic POM was sampled by collecting bare sediment (benthic microbial and microalgal mats are not a prominent feature in the estuaries of Waquoit Bay) to a depth of $1 \mathrm{~cm}$ at 10 locations within each estuary. Sediment type in all 3 estuaries is a mixture of sand, silt, and clay. Benthic macrophytes were sampled from 15 locations within each estuary. Benthic invertebrates were sampled with an Ekman dredge from 15 locations within Sage Lot Pond and Childs River Drenge contents were rinsed through a $1 \mathrm{~mm}$ sieve and invertebrate species retained on the sieve were sorted by species. Fish were collected from Sage Lot Pond and Childs River by seine.

Sample preparation. To prepare samples for stable isotope analysis, phytoplankton and suspended POM were filtered from water samples onto precombusted $\left(490^{\circ} \mathrm{C}\right)$ Gelman A/E glass fiber filters with a low pressure vacuum pump, macrophytes were gently cleaned of epiphytic material, and animals were held in filtered sea water for $24 \mathrm{~h}$ to allow their guts to clear. Both macrophytes and animals were then rinsed with deionized water, and all samples were dried at $60^{\circ} \mathrm{C}$. When dry, samples were ground (filters with POM were kept whole) into a homogenous powder, and combined to make single composite samples of each species per estuary per sampling date. Whole organisms were used in all cases except for Mya arenaria and Geukensia demissa, the shells of which were removed. Separate composites consisting of 15 to 250 individuals (depending on the size of the species collected) were prepared for stable isotope analysis from each estuary for each season. Samples for stable carbon isotope analysis were acidified to remove inorganic carbon, then dried and ground a second time.

Stable isotope analysis. Samples were analyzed in the Boston University Stable Isotope Laboratory using a Finnigan Delta-S isotope ratio mass spectrometer. All samples (except filters, see below) were weighed and loaded into tin capsules and combusted in a Heraeus element analyzer. The resulting combustion gases were cryogenically separated and purified in a Finnigan CT-CN trapping box before introduction into the mass spectrometer. Filters were acidified with $\mathrm{PtCl}_{2}$, dried, then combusted using the Dumas combustion technique. Combustion gases were again separated and purified before analysis (Lajtha \& Michener 1994).
The standard used for stable nitrogen isotope analysis was $\mathrm{N}_{2}$ in air, and the standard used for stable carbon isotope analysis was Vienna Peedee belemnite. $\delta^{13} \mathrm{C}$ and $\delta^{15} \mathrm{~N}$ values, expressed as \%, were calculated as $\left[\left(R_{\text {sample }} / R_{\text {standard }}\right)-1\right] \times 10^{3}$, with $R$ equal to ${ }^{15} \mathrm{~N} /{ }^{14} \mathrm{~N}$ or ${ }^{13} \mathrm{C} /{ }^{12} \mathrm{C}$. Precision of replicate analyses was $\pm 0.2 \%$ for nitrogen and $\pm 0.3 \%$ for carbon.

\section{RESULTS AND DISCUSSION}

In the sections below, we first examine the stable carbon and nitrogen isotope values of primary producers in Sage Lot Pond, Quashnet River, and Childs River. We then discuss the relationship between isotope values of POM, and isotope values of dominant producers in each estuary. Finally, we use stable carbon and nitrogen isotope values to compare the food webs in Sage Lot Pond and Childs River, and discuss changes in the flow of land-derived nitrogen into food webs as eutrophication intensifies. Although we focus our analysis on the producers that contribute most to production within the estuaries of Waquoit Bay (Table 1), we acknowledge that a variety of less prominent producers must also contribute to POM and to the diets of consumers.

\section{Stable isotope values of primary producers}

The $\delta^{13} \mathrm{C}$ values of primary producers (except for the macroalga Gracilaria tikvahiae, see below) change little among estuaries, while the $\delta^{15} \mathrm{~N}$ values of primary producers consistently differ among estuaries (Table 2). The similarity of producer $\delta^{13} \mathrm{C}$ is reasonable because the $\delta^{13} \mathrm{C}$ of dissolved inorganic carbon (DIC) largely depends on salinity (Fogel et al. 1992), and producers were sampled from waters of the same salinity range at all estuaries. As discussed in the introduction, differences in $\delta^{15} \mathrm{~N}$ values of producers among estuaries are linked to differences in $\mathrm{N}$ loading from wastewater (McClelland et al. 1997. McClelland \& Valiela in press). Both $\delta^{15} \mathrm{~N}$ and $\delta^{13} \mathrm{C}$ of producers change little among seasons (Table 2), suggesting that the isotope values of DIN and DIC, and the fractionation associated with their use, do not vary much throughout the year within the Waquoit Bay system.

Unlike the other producers, the $\delta^{13} \mathrm{C}$ of Gracilaria tikvahiae in Sage Lot Pond is substantially lower than at the other 2 estuaries (Table 2). The reason for this anomaly is unclear. Perhaps increased nitrogen availability in Childs River and Quashnet River allows G. tikvahiae to incorporate carbon more efficiently than in Sage Lot Pond, so that fractionation of DIC during uptake by this species becomes smaller 
Table 2. Primary producer and POM isotope values (\%) of composite samples collected spring, summer, and fall between 1993 and 1996 from Sage Lot Pond, Quashnet River, and Childs River (average \pm 1 SE). Values in parentheses are number of seasons sampled. Values in italics are estimates of phytoplankton isotope values based on measured values at Childs River

\begin{tabular}{|c|c|c|c|c|c|c|}
\hline & \multicolumn{2}{|c|}{ Sage Lot Pond } & \multicolumn{2}{|c|}{ Quashnet River } & \multicolumn{2}{|c|}{ Childs River } \\
\hline & $\delta^{13} \mathrm{C}$ & $\delta^{15} \mathrm{~N}$ & $\delta^{13} \mathrm{C}$ & $\delta^{15} \mathrm{~N}$ & $\delta^{13} \mathrm{C}$ & $\delta^{15} \mathrm{~N}$ \\
\hline POM (Suspended) & $-18.4 \pm 1.4(5)$ & $3.7 \pm 0.3(5)$ & $-19.9 \pm 0.7(3)$ & $4.3 \pm 0.5(3)$ & $-20.0 \pm 0.2(4)$ & $5.6 \pm 0.3(4)$ \\
\hline POM (Benthic) & $-15.2 \pm 0.5(2)$ & $2.4 \pm 0.3(2)$ & $-17.4(1)$ & $3.7(1)$ & $-17.8 \pm 0.1(2)$ & $5.1 \pm 0.1(2)$ \\
\hline \multicolumn{7}{|l|}{ Primary producers } \\
\hline Phytoplankton & -21.1 & 5.1 & -21.1 & 6.1 & $-21.1(1)$ & $7.1(1)$ \\
\hline \multicolumn{7}{|l|}{ Macroalgae } \\
\hline Cladophora vagabunda & $-15.3 \pm 0.3\{4\}$ & $3.4 \pm 0.1(4)$ & $-15.2 \pm 0.2(3)$ & $4.0 \pm 0.1(3)$ & $-15.3 \pm 0.1(4)$ & $5.4 \pm 0.1(4)$ \\
\hline Gracilaria tikvahiae & $-19.5 \pm 0.6(4)$ & $5.1 \pm 0.6(4)$ & $-16.9 \pm 1.0(3)$ & $5.9 \pm 0.3(3)$ & $-16.7 \pm 0.3(4)$ & $7.6 \pm 0.4(4)$ \\
\hline Enteromorpha sp. & $-19.1 \pm 2.1(2)$ & $4.9 \pm 0.1(2)$ & $-17.7 \pm 0.6(2)$ & $6.4 \pm 0.3(2)$ & $-18.7 \pm 1.1(2)$ & $8.4 \pm 0.2(2)$ \\
\hline \multicolumn{7}{|l|}{ Eelgrass } \\
\hline Zostera marina & $-7.1 \pm 0.5(4)$ & $0.2 \pm 0.6(4)$ & $-8.1(1)$ & $0.4(1)$ & $-7.4(1)$ & $6.1(1)$ \\
\hline
\end{tabular}

under higher $\mathrm{N}$ loading conditions (B. Peterson pers. comm.).

Although the stable isotope values of phytoplankton in Waquoit Bay were determined from populations grown up under artificial conditions (see 'Methods'), the values are typical of those measured for marine phytoplankton in many locations around the world (Gearing 1988). In fact, our estimate of phytoplankton $\delta^{13} \mathrm{C}$ in Waquoit Bay $(-21.1 \%)$ is almost identical to the average $\delta^{13} \mathrm{C}$ value of phytoplankton $(-21.3 \pm 1.1 \%)$ in nearby Narragansett Bay, Rhode Island (Gearing et al. 1984). Based on this similarity, we conclude that any non-phytoplankton particles in our 'phytoplankton' samples did not measurably influence the isotope values of these samples.

\section{Composition of POM}

The $\delta^{13} \mathrm{C}$ values of POM fall between those of phytoplankton and macroalgae at all of the Waquoit Bay estuaries (Fig. 2), indicating that these 2 producer types are the dominant contributors to POM throughout the system. It is apparent from the higher $\delta^{13} \mathrm{C}$ values of POM in Sage Lot Pond compared to the other 2 estuaries (Fig. 2), however, that eelgrass makes an important contribution to POM in Sage Lot Pond in addition to phytoplankton and macroalgae.

Salt-marsh cordgrass Spartina alterniflora is more abundant at Sage Lot Pond that at the other 2 estuaries. It is therefore possible that inputs from $S$. alterniflora $\left(\delta^{13} \mathrm{C}=-12.5 \%\right)$ contribute to the higher $\delta^{13} \mathrm{C}$ values of POM in Sage Lot Pond (Fig. 2). We estimate the influence of $S$. alterniflora to be small, however, because the proportion of primary production in Sage Lot Pond coming from S. alterniflora is only about $10 \%$ (WBLMER unpubl. data). This estimate is based on the assumption that $20 \%$ of net aerial production (total organic carbon) by $S$. alterniflora typically makes it into the open waters of salt-marsh estuaries (Taylor \& Allanson 1995). In fact, however, the hydrology and geomorphology of the Waquoit Bay system are such that inputs from $S$. alterniflora may even be smaller. The low tidal amplitude in Waquoit Bay is conducive to salt-marsh banks that drop off vertically from the marsh surface into the water. As a consequence, creek banks with the tall form of $S$. alterniflora that get flooded twice daily are almost non-existent. The surface of the marsh is only flooded infrequently, and thus remains uncoupled from the estuary much of the time. This situation is consistent with the finding of Deegan \& Garritt (1997) that salt-marsh production does not contribute significantly to subtidal food webs in estuaries with low tidal amplitudes.

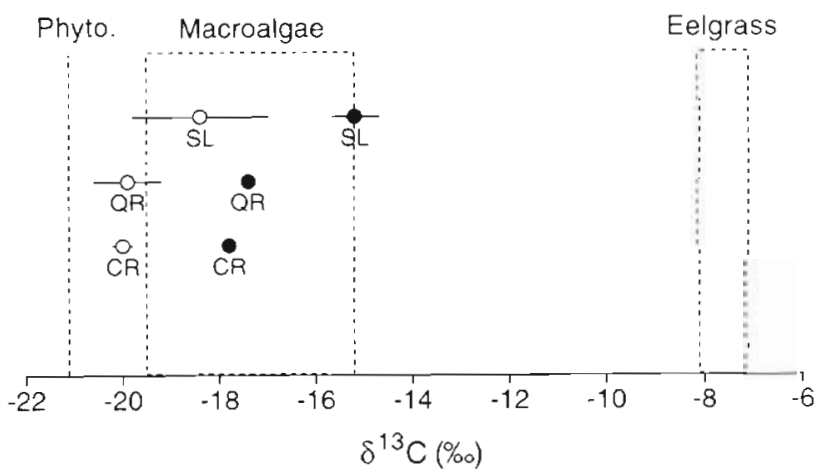

Fig. 2. $\delta^{13} \mathrm{C}$ values of suspended (O) and benthic ( $)$ POM in Sage Lot Pond (SL), Quashnet River (QR), and Childs River (CR) compared to those of phytoplankton (Phyto.), macroalgae, and eelgrass in Waquoit Bay. Dashed lines indicate the ranges of $\delta^{13} \mathrm{C}$ values for each producer type. 
Table 3. Percentage of POM and primary consumer diets consisting of eelgrass Zostera marina within the Sage Lot Pond estuary (average $\pm 1 \mathrm{SD}$ ). Estimates are calculated from the difference in $\delta^{i 3} \mathrm{C}$ of consumers (and POM) living in Childs River and Sage Lot Pond. Sp.: spring; Su.. summer, F.. fall

\begin{tabular}{|llc|}
\hline & Seasons in average & Percent eelgrass \\
\hline Suspended POM & F., Su., Su., Sp. & $17 \pm 10$ \\
Benthic POM & Su., Su. & $23 \pm 5$ \\
Suspension feeders & & \\
Geukensia demissa & Sp. & 0 \\
Mya arenaria & Su. Su. & $10 \pm 3$ \\
Deposit/detritus feeders & F., Su., Su., Sp. & $27 \pm 4$ \\
Sclerodactyla briareus & Su. & 12 \\
Palaemonetes vulgaris & Su. & 13 \\
Leitoscoloplos tragilis & Su. & 15 \\
Leptosynapta sp. & F., Su., Su. & $31 \pm 8$ \\
Herbivores & Su., Su. & $16 \pm 1$ \\
Cyprinodon variegatus & Su. & 11 \\
Cymadusa compta & Su., Sp. & $12 \pm 12$ \\
Gammarus mucronatus & Su., Su. & $16 \pm 2$ \\
Erichsonella filiformis & & \\
Microdeutopus gryllotalpa & & \\
\end{tabular}

eelgrass $\delta^{13} \mathrm{C}$ and the $\delta^{13} \mathrm{C}$ of POM at Childs River represents a $100 \%$ loss of eelgrass. Thus, the slope term in the above equation is 100 divided by the difference between eelgrass $\delta^{13} \mathrm{C}$ and the $\delta^{13} \mathrm{C}$ of POM at Childs River There is no $y$-intercept term because the $\delta^{13} \mathrm{C}$ values of POM at Sage Lot Pond and Childs River are expected to be the same if POM at Sage Lot Pond contains no eelgrass.

Our estimates of the percentage of eelgrass in POM (Table 3) are probably conservative, because the larger contribution to production by Cladophora vagabunda in Childs River compared to Sage Lot Pond (Table 1) counters the decrease in $\delta^{13} \mathrm{C}$ of POM caused by a loss of eelgrass. Nonetheless, our estimates for Sagje Lot Pond are quite similar to estimates by Thayer et al. (1978) for benthic (29\%) and suspended $(18 \%)$ POM in the Newport River Estuary, North Carolina (also based on $\delta^{13} \mathrm{C}$ ).

The consistently lower $\delta^{13} \mathrm{C}$ values of suspended POM compared to benthic POM at all 3 estuaries (Fig. 2) indicate that suspended POM contains a larger proportion of phytoplankton than does benthic POM. This is not surprising, given that phytoplankton production takes place in the water column. What is more interesting, however, is that suspended POM at all of the estuaries contains organic matter from benthic producers. Benthic macrophytes may be contributing to suspended POM (1) as sloughed particles, (2) as resuspended detritus from the sediments or (3) as organic aggregates formed by bacteria in association with macrophyte-derived dissolved organic matter (Alber \& Valiela 1994). In any case, the $\delta^{13} \mathrm{C}$ data for POM in the Waquoit Bay estuaries highlights the importance of benthic-pelagic coupling in shallow estuaries.

Based on the decrease in $\delta^{13} \mathrm{C}$ between Sage Lot Pond and Childs River (Fig. 2), we estimate that (as an annual average) benthic POM is $23 \%$ eelgrass and suspended POM is $17 \%$ eelgrass in Sage Lot Pond (Table 3). These percentages were calculated from the equation

$\%$ eelgrass $=$

$$
\frac{100}{\delta^{13} \mathrm{C}_{\text {eelgrass }}-\delta^{13} \mathrm{C}_{\mathrm{POM}}} \times\left(\delta^{13} \mathrm{C}_{\mathrm{POM}}-\delta^{13} \mathrm{C}_{\mathrm{POM}}\right)
$$

where CR and SL represent Childs River and Sage Lot Pond respectively, and POM is either benthic or suspended particulate organic matter This equation expresses a simple linear relationship between \% eelgrass and the decrease in $\delta^{13} \mathrm{C}$ of POM between Sage Lot Pond and Childs River. The difference between
Contributions by eelgrass $\left(\delta^{13} \mathrm{C}=-7 \%\right)$ to $\mathrm{POM}$ in Sage Lot Pond appear to change seasonally (Fig. 3, top panel). The $\delta^{13} \mathrm{C}$ of suspended POM is highest during summer months, when eelgrass biomass peaks within the estuary, and lowest in the fall and spring, when eelgrass biomass is relatively low. In the other 2 estuaries, where eelgrass is virtually absent, $\delta^{13} \mathrm{C}$ values of POM change little among seasons (Table 2). Using Eq. (1), we find that contributions of eelgrass to suspended POM are undetectable during fall and spring, but that in summer (when eelgrass biomass peaks in Sage Lot Pond), suspended POM consists of approximately $34 \%$ eelgrass (Table 4 ). The timing of the relationship between eelgrass biomass and suspended POM in Sage Lot Pond suggests that release of eelgrass-derived organic matter into the water column is closely coupled to active growth of eelgrass. Formation of organic aggregates from DOM released by eelgrass (Alber \& Valiela 1994) is probably an important mechanism behind this coupling.

As with $\delta^{13} \mathrm{C}$, differences in the $\delta^{15} \mathrm{~N}$ values of POM among estuaries are consistent with differences in eelgrass contributions; the $\delta^{15} \mathrm{~N}$ values of POM are lower at Sage Lot Pond than at the other 2 estuaries (Table 2). Differences in the $\delta^{15} \mathrm{~N}$ values of primary producers among estuaries (as a result of differences in wastewater inputs), however, make it difficult to quantify the relationship between eelgrass contributions and POM $\delta^{15} \mathrm{~N}$ At most, we deduce from the different responses of $\delta^{13} \mathrm{C}$ and $\delta^{15} \mathrm{~N}$ in POM to seasonal contributions of eelgrass (Fig. 3) that nitrogen from eelgrass makes a smaller contribution to POM than does carbon from 


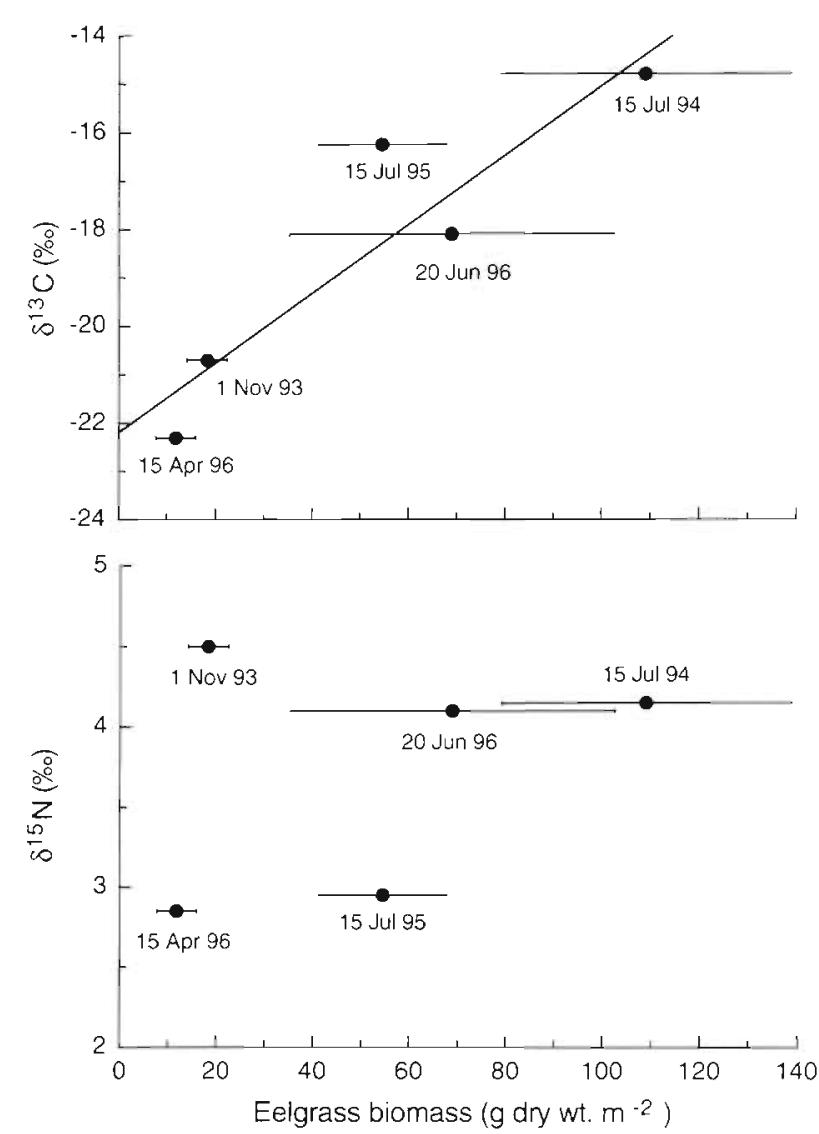

Fig. 3. Biomass of eelgrass Zostera marina versus $\delta^{13} \mathrm{C}$ (top) and $\delta^{15} \mathrm{~N}$ (bottom) of suspended POM at various times of year in Sage Lot Pond. Estimates of eelgrass biomass are from monthly samples $(n=10)$ collected with an Ekman dredge. Eelgrass blades were removed from rhizomes, cleaned of epiphytic material, rinsed with fresh water, dried at $60^{\circ} \mathrm{C}$, and weighed. Averages \pm 1 SD were then calculated for each month

eelgrass. This is reasonable, given the higher $\mathrm{C}: \mathrm{N}$ of eelgrass compared to phytoplankton and macroalgae (Duarte 1992). Immobilization of inorganic nitrogen by heterotrophic bacteria associated with detritus (Rice \&

Table 4. Seasonal comparison of the percentage of eelgrass Zostera marina contributing to suspended POM and to the diets of sea cucumbers Sclerodactyla briareus, sheeps head minnow Cyprinodon variegatus, and isopods Erichsonella filiformis at Sage Lot Pond. Averages \pm 1 SE are reported where samples were collected during more than one season

\begin{tabular}{|lrccc|}
\hline \multirow{2}{*}{ Season } & \multicolumn{4}{c|}{ Percentage eelgrass contributing to: } \\
& Susp. POM & S. briareus & C. variegatus & E. filiformis \\
\hline Fall + spring & $0 \pm 0$ & $30 \pm 8$ & 16 & 0 \\
Summer & $34 \pm 7$ & $25 \pm 6$ & $39 \pm 5$ & 24 \\
\hline
\end{tabular}
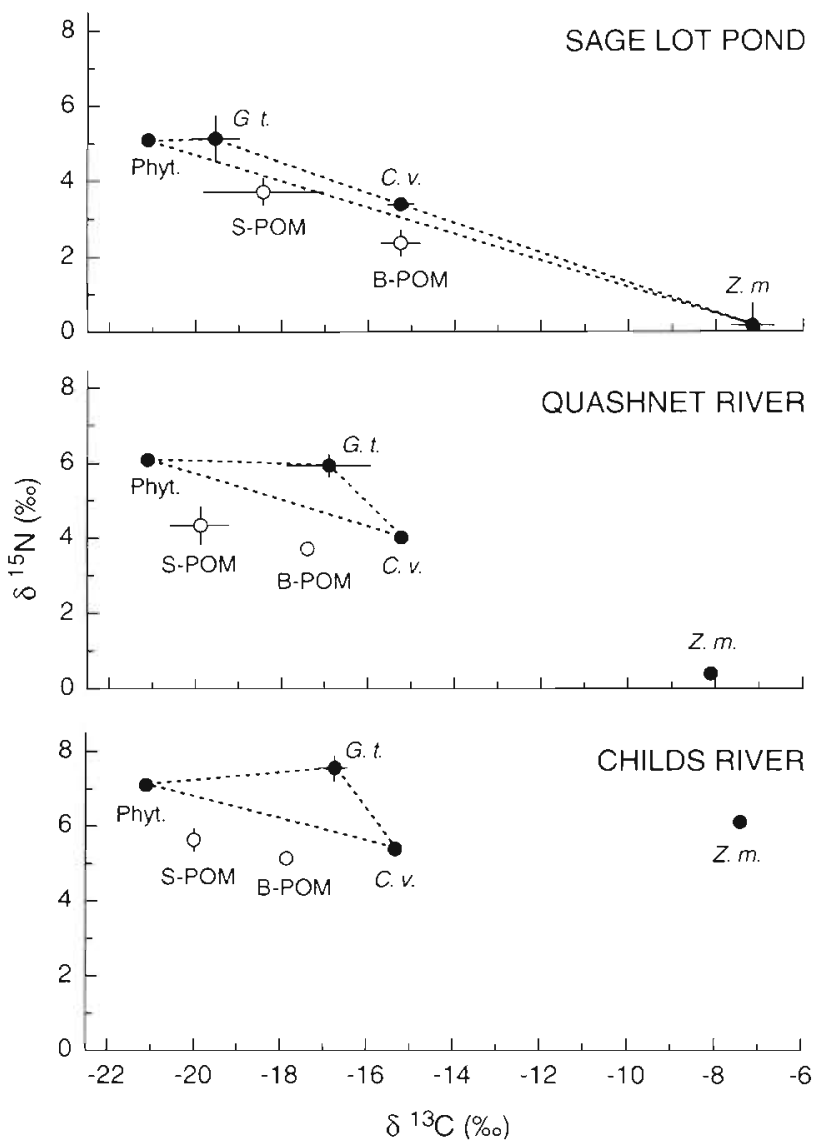

Fig. 4. $\delta^{13} \mathrm{C}$ versus $\delta^{15} \mathrm{~N}$ of POM (O) compared to $\delta^{13} \mathrm{C}$ versus $\delta^{15} \mathrm{~N}$ of the dominant primary producers ( ) at Sage Lot Pond, Quashnet River, and Childs River. Phyt. = phytoplankton, G. t. = Gracilaria tikvahiae, C. v. = Cladophora vagabunda, Z. $m$. = Zostera marina, $\mathrm{S}-\mathrm{POM}=$ suspended POM, B-POM = benthic POM. Dashed lines connect the dominant producers within each estuary (Table 1). Areas enclosed by the dashed lines indicate where points for POM are expected to fall when POM consists of a mix of the dominant producers

Hanson 1984) may also uncouple the $\delta^{15} \mathrm{~N}$ signal from the $\delta^{13} \mathrm{C}$ signal of eelgrass. Zieman et al. (1984), however, found that the $\delta^{15} \mathrm{~N}$ values of 2 seagrass species in Florida did not change during early decomposition.

In dual isotope plots $\left(\delta^{13} \mathrm{C}\right.$ vs $\left.\delta^{15} \mathrm{~N}\right)$, points for POM consistently fall below the area where they are predicted to fall based on a mix of the dominant producers in each estuary (Fig. 4). This suggests that the $\delta^{15} \mathrm{~N}$ of producers decrease by a small but consistent amount during decomposition. Currin et al. (1995) found that the $\delta^{15} \mathrm{~N}$ of standing dead cordgrass decreased by about $2.4 \%$ over a 10 mo period. The extent to which stable isotope values of algae change during decomposition have received less study. Based on our data from Childs River (where over $80 \%$ 
Table 5. Consumer isotope values (\%) of composite samples collected in spring, summer, and fall between 1993 and 1996 from Sage Lot Pond, and Childs River (average $\pm 1 \mathrm{SE}$ ). Values in parentheses are number of seasons sampled. B: bivalve; $P$ : polychaete; C: crustacean; $\mathrm{H}$ : holothurian; F: fish

\begin{tabular}{|c|c|c|c|c|}
\hline & \multicolumn{2}{|c|}{ Sage Lot Pond } & \multicolumn{2}{|c|}{ Childs River } \\
\hline & $\delta^{13} \mathrm{C}$ & $\delta^{15} \mathrm{~N}$ & $\delta^{13} \mathrm{C}$ & $\delta^{15} \mathrm{~N}$ \\
\hline \multicolumn{5}{|l|}{ Primary consumers } \\
\hline \multicolumn{5}{|l|}{ Suspension feeders } \\
\hline Geukensia demissa, B & $-19.0(1)$ & $7.3(1)$ & $-18.5(1)$ & $9.1(1)$ \\
\hline Mya arenaria, $\mathrm{B}$ & $-16.0 \pm 0.5(2)$ & $5.3 \pm 0.4(2)$ & $-17.1 \pm 0.2(2)$ & $7.9 \pm 0.0(2)$ \\
\hline \multicolumn{5}{|l|}{ Deposit/detritus feeders } \\
\hline Cirratulus grandis, $\mathrm{P}$ & $-14.7 \pm 0.2\{2\}$ & $5.1 \pm 0.3(2)$ & - & - \\
\hline Leitoscoloplos fragilis, $\mathrm{P}$ & $-13.5 \pm 0.3(2)$ & $4.5 \pm 0.6(2)$ & $-14.4(1)$ & $7.5(1)$ \\
\hline Palaemonetes vulgaris, $\mathrm{C}$ & $-12.6(1)$ & $5.8(1)$ & $-13.6(1)$ & $8.8(1)$ \\
\hline Leptosynapta sp., $\mathrm{H}$ & $-13.4(1)$ & $6.1(1)$ & $-14.7(1)$ & $9.4(1)$ \\
\hline Sclerodactyla briareus, $\mathrm{H}$ & $-13.4 \pm 0.2(4)$ & $6.7 \pm 0.1(4)$ & $-16.0 \pm 0.2(4)$ & $10.3 \pm 0.4(4)$ \\
\hline \multicolumn{5}{|l|}{ Herbivores } \\
\hline Cyprinodon variegatus, $F$ & $-11.5 \pm 0.9\{3\}$ & $5.2 \pm 0.5(3)$ & $-14.0 \pm 0.5(3)$ & $9.8 \pm 0.3(3)$ \\
\hline Cymadusa compta, C & $-14.4 \pm 0.3(2)$ & $4.1 \pm 0.2(2)$ & $-16.0 \pm 0.4(2)$ & $7.6 \pm 0.2\{2\}$ \\
\hline Gámmarus mucronatus, C & $-14.2(1)$ & $5.1(1)$ & $-14.8 \pm 0.4(2)$ & $7.8 \pm 0.3(2)$ \\
\hline Erichsonella filiformis, $\mathrm{C}$ & $-13.6 \pm 1.8(2)$ & $4.3 \pm 1.0(2)$ & $-14.5 \pm 0.6(2)$ & $7.7 \pm 0.8(2)$ \\
\hline Microdeutopus gryllotalpa, C & $-13.4 \pm 0.1(2)$ & $3.8 \pm 0.1(2)$ & $-14.8 \pm 0.4(2)$ & $6.6 \pm 0.1(2)$ \\
\hline \multicolumn{5}{|l|}{ Secondary consumers } \\
\hline Menidia menidia, $\mathrm{F}$ & $-16.5 \pm 0.5(4)$ & $9.8 \pm 0.4(4)$ & $-17.7 \pm 0.8(4)$ & $11.6 \pm 0.3(4)$ \\
\hline Gasterosteus aculeatus, $\mathrm{F}$ & $-16.9(1)$ & $9.0(1)$ & $-15.4 \pm 0.4(3)$ & $12.3 \pm 0.4(3)$ \\
\hline Fundulus heteroclitus, F & $-14 \pm 0.4(3)$ & $8.3 \pm 0.2(3)$ & $-14.6 \pm 0.5(3)$ & $11.3 \pm 0.3(3)$ \\
\hline Pseudopleuronectes americanus, F & - & - & $-13.1(1)$ & $10.7(1)$ \\
\hline Podarke obscura, $\mathrm{P}$ & $-12.7 \pm 0.2(4)$ & $7.1 \pm 0.1(4)$ & $-14.9 \pm 0.2(4)$ & $10.7 \pm 0.3(4)$ \\
\hline
\end{tabular}

of production comes from phytoplankton and Cladophora vagabunda; Table 1), it appears that decomposition has decreased the $\delta^{15} \mathrm{~N}$ of algae by about $1 \%$. This decrease in $\delta^{15} \mathrm{~N}$ may be due to uptake of inorganic nitrogen by bacteria associated with detritus (Rice 1982). Rice \& Hanson (1984) demonstrated that bacterially mediated $\mathrm{N}$ accumulation in cordgrass detritus was greater than $\mathrm{N}$ accumulation in macroalgal (Gracilaria foliifera) detritus. This would explain the larger difference in $\delta^{15} \mathrm{~N}$ between live and decomposed cordgrass observed by Currin et al. (1995) than between live and decomposed algae observed in this study (Fig. 4).

\section{Food sources of consumers}

Before comparing the stable isotope values of consumers with those of potential food sources within the Waquoit Bay estuaries, we corrected for fractionation that occurs as organic matter passes from one trophic level to the next. This was done by subtracting literature values for trophic fractionation from the measured isotope values of consumers presented in Table 5. $1.0 \%$ was subtracted from the $\delta^{13} \mathrm{C}$ and $\delta^{15} \mathrm{~N}$ values of amphipods (and one isopod) to account for the trophic fractionation measured by Macko et al. (1982) for these consumers. For all other consumers, $1.0 \%$ was sub- tracted from $\delta^{13} \mathrm{C}$, and $3.0 \%$ was subtracted from $\delta^{15} \mathrm{~N}$. These values reflect an average fractionation effect of a trophic step based on a broad range of consumer types (Peterson \& Fry 1987, Michener \& Schell 1994).

Primary consumers. The positions of primary consumers compared to those of producers in $\delta^{13} \mathrm{C}$ versus $\delta^{15} \mathrm{~N}$ plots for Sage Lot Pond (Fig. 5) and Childs River (Fig. 6) indicate that the dominant producers found in each estuary are important food sources. Primary consumers in Sage Lot Pond (Fig. 5) eat phytoplankton, macroalgae, and eelgrass, whereas primary consumers in Childs River (Fig. 6) subsist on phytoplankton and macroalgae alone.

The presence of eelgrass in the diets of primary consumers in Sage Lot Pond is confirmed by shifts in $\delta^{13} \mathrm{C}$ values of primary consumers between Sage Lot Pond and Childs River (Fig. 7). Shifts in the $\delta^{15} \mathrm{~N}$ values of consumers between Sage Lot Pond and Childs River (Table 5) also reflect differences in eelgrass abundance between estuaries, but these shifts are confounded by shifts in producer $\delta^{15} \mathrm{~N}$ (Table 2) as a result of differences in $\mathrm{N}$ loading from wastewater (McClelland et al. 1997, McClelland \& Valiela in press). We therefore focus on shifts in $\delta^{13} \mathrm{C}$ between Sage Lot Pond and Childs River to estimate the proportions of primary consumer diets derived from eelgrass in Sage Lot Pond. We use Eq. (1), but substitute 'consumers' for 'POM' and ' $\left(\delta^{13} \mathrm{C}_{\text {eelgrass }}+1\right)$ ' for ' $\delta{ }^{13} \mathrm{C}_{\text {eelgrass'. We add } 1 \text { to }}$ 


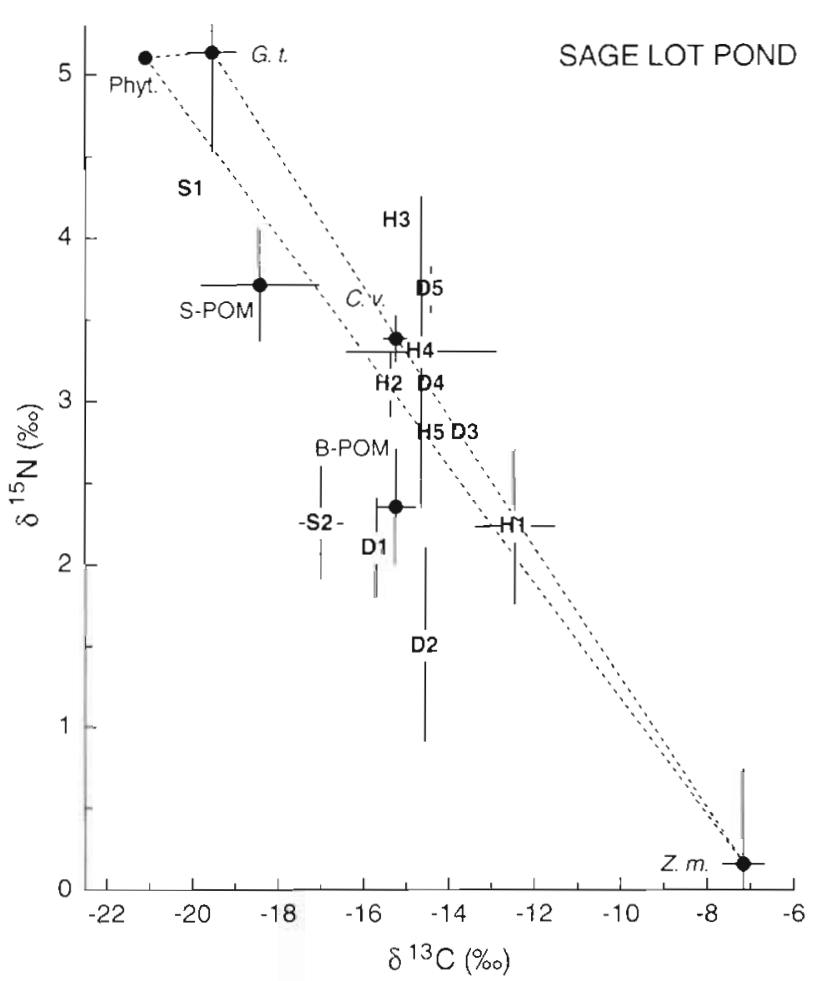

Fig. 5. $\delta^{13} \mathrm{C}$ versus $\delta^{15} \mathrm{~N}$ of primary consumers (with adjustment for trophic fractionation, see below compared to $\delta^{13} \mathrm{C}$ versus $\delta^{15} \mathrm{~N}$ of POM and the dominant producers in Sage Lot Pond Suspension feeders $\$ 1$ = Geukensia demissa, $\mathrm{S} 2=$ Mya arenaria. Herbivores: $\mathrm{H} 1=$ Cyprinodon variegatus, $\mathrm{H}_{2}=$ Cymadusa compta, $\mathrm{H} 3=$ Gammarus mucronatus, $\mathrm{H} 4=$ Erichsonella filiformis, H5 = Microdeutopus gryllotalpa. Deposit $/$ detritus feeder: 01 = Cirratulus grandis, D2 = Leitoscoloplos fragilis, $\mathrm{D} 3=$ Palaemonetes vulgaris, $\mathrm{D} 4=$ Leptosynapta $\mathrm{sp}$. D5 = Sclerodactyla briareus. Phyt. = phytoplankton, $G$. $t .=$ Gracilaria tikvahiae, $C . v .=$ Cladophora vagabunda, $Z . m .=$ Zostera marina, S-POM = suspended POM, B-POM = benthic POM. Dashed lines encompass the areas where points for primary consumers are expected to fall when their diets consist of a mix of the dominant producers in Sage Lot Pond. $1 \%$ has been subtracted from the stable $C$ and $N$ isotope values of small crustacean grazers to correct for trophic fractionation $1 \%$ and $3 \%$ have been subtracted from the $\delta^{13} \mathrm{C}$ and $\delta^{15} \mathrm{~N}$ values respectively of all other consumers

the $\delta^{13} \mathrm{C}$ value of eelgrass to account for trophic fractionation

Sage Lot Pond: Using Eq. (1), we estimate that eelgrass makes a relatively small contribution to the diets of most consumers in Sage Lot Pond (typically less than $16 \%$ ), and yet its presence in the food web of Sage Lot Pond is pervasive (Table 3). Furthermore, it is apparent that eelgrass is more important in the diets of some consumers than others; the sea cucumber Sclerodactyla briareus and the sheepshead minnow Cyprinodon variegatus stand out as having particularly large proportions of eelgrass in their diets, while the ribbed

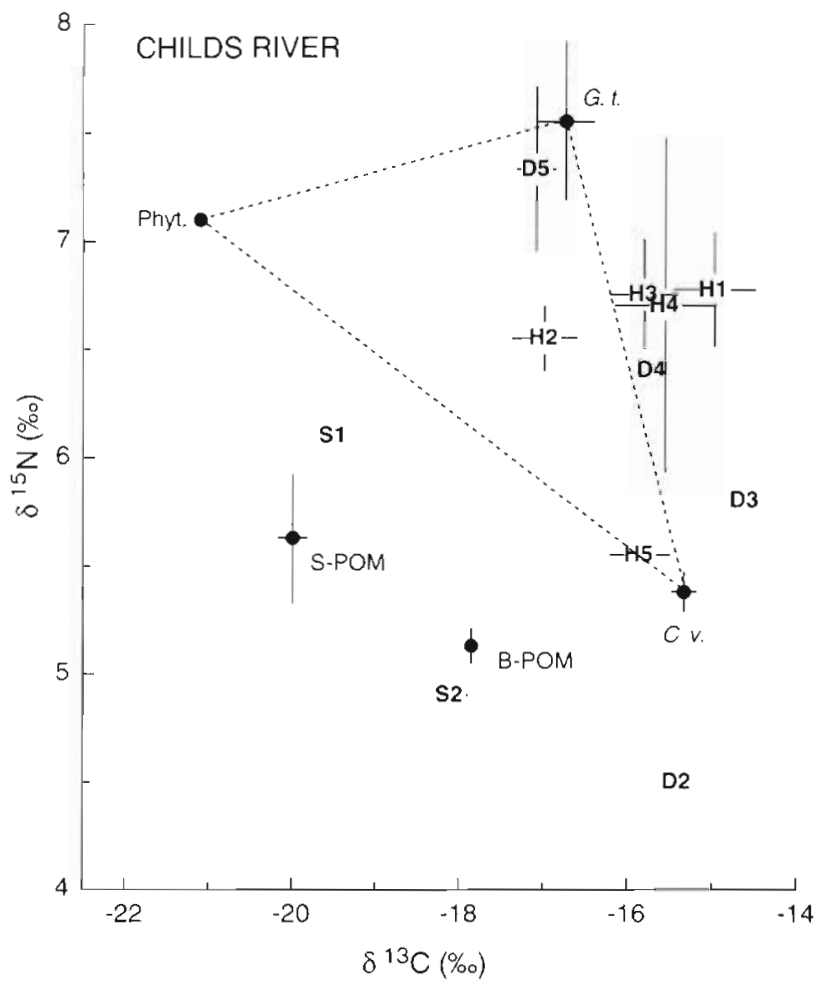

Fig. 6. $\delta^{13} \mathrm{C}$ versus $\delta^{15} \mathrm{~N}$ of primary consumers (with adjustment for trophic fractionation, see below) compared to $\delta^{13} \mathrm{C}$ versus $\delta^{15} \mathrm{~N}$ of POM and the dominant producers in Childs Ruver. Suspension feeders: S1 = Geukensia demissa, $\mathrm{S} 2=$ Mya

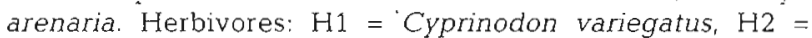
Cymadusa compta, $\mathrm{H} 3$ = Gammarus mucronatus, $\mathrm{H} 4=$ Erich sonella filiformis, H5 = Microdeutopus gryllotalpa. Deposit/ detritus feeder: D2 = Leitoscoloplos fragilis, D3 = Palaemonetes vulgaris, $\mathrm{D} 4=$ Leptosynapta sp., D5 = Sclerodactyla briareus. Phyt $=$ phytoplankton, G. $t .=$ Gracilaria tikvahiae, C. $v$. = Cladophora vagabunda, Z. $\mathrm{m}$. = Zostera marina, $\mathrm{S}-\mathrm{POM}=$ suspended POM, B-POM = benthic POM. Dashed lines encompass the areas where points for primary consumers are expected to fall when their diets consist of a mix of the dominant producers in Childs River. To correct for trophic fractionation, $1 \%$ was subtracted from the stable $\mathrm{C}$ and $\mathrm{N}$ isotope values of small crustacean grazers. $1 \%$ and $3 \%$ were subtracted from the $\delta^{13} \mathrm{C}$ and $\delta^{15} \mathrm{~N}$ values respectively of all other primary consumers

mussel Geukensia demissa has no detectable eelgrass in its diet (Table 3 ).

The difference in diet between the ribbed mussel and the soft-shell clam in Sage Lot Pond (Table 3), even though they are both suspension feeders, is likely a result of the different locations within the estuary where each species lives. Ribbed mussels in Sage Lot Pond live embedded in the salt-marsh bank at the estuary's edge, just below the marsh surface. In this location, they can only feed near high tide, and thus have diets dominated by phytoplankton (Fig. 5). On the other hand, soft shell clams in Sage Lot Pond live 


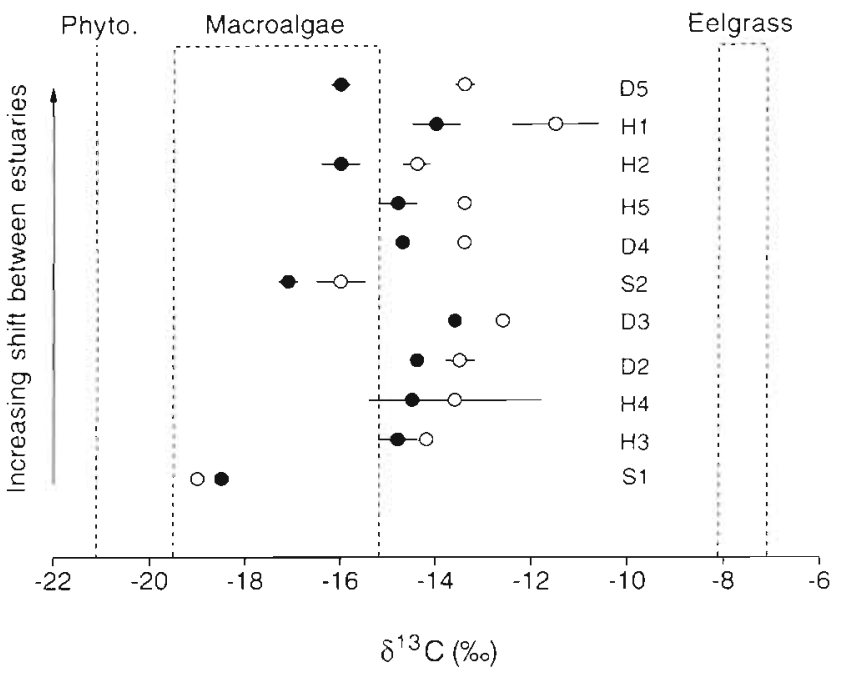

Fig $7 \quad{ }^{13} \mathrm{C}$ values of primary consumers (without adjustment for trophic fractionation) at Sage Lot Pond (0) and Childs River (-) compared to those of phytoplankton (Phyto.), macroalgae, and eelgrass in Waquoit Bay. Dashed lines indicate the ranges of $\delta^{13} \mathrm{C}$ values for each producer type. Suspension feeders: S1 = Geukensia demissa, S2 = Mya arenaria. Herbivores: $\mathrm{H} 1$ = Cyprinodon variegatus, $\mathrm{H} 2=$ Cymadusa compta, $\mathrm{H} 3=$ Gammarus mucronatus, $\mathrm{H} 4=$ Erichsonella filiformis, H.5 = Microdeutopus gryllotalpa. Deposit/detritus feeder: D2 = Leitoscoloplos fragilis, D3 = Palaemonetes vul garis, D4 = Leptosynapta sp., D5 = Sclerodactyla briareus. Primary consumers are ordered from the bottom to the top of the figure according to increasing difference in $\delta^{13} \mathrm{C}$ between estuaries

largely subtidally on the bottom of the estuary, and their diets have a large benthic component (Fig. 5), including a contribution from eelgrass (Table 3). Peterson et al. (1985) similarly suggest that the different subhabitats of ribbed mussels compared to quahogs Mercenaria mercenaria are responsible for the larger proportion of phytoplankton found in the diets of ribbed mussels compared to hard-shell clams within Great Sippewissett Marsh. Cape Cod, Massachusetts.

Where we had sufficient data, we also looked for seasonal differences in the percentage of eelgrass in the diets of primary consumers. As with suspended POM, the sheepshead minnow Cyprinodon variegatus and the isopod Erichsonella filiformis are influenced by eelgrass more in summer than winter months (Table 4). This seasonali:y suggests that these herbivores feed at least partially on live eelgrass. The sea cucumber Sclerodactyla briareus, on the other hand, shows no seasonal shift in the percentage of eelgrass contributing to its diet (Table 4). This is consistent with the detritus feeding habit of $S$. briareus. Eelgrass detritus becomes more edible as it decays (Tenore et al. 1982), and thus seasonal inputs of live eelgrass are temporally separated from the detritus pool used by $S$. briareus. In ad- dition, S. briareus may consume eelgrass detritus that spans several (even many) seasons from day to day.

Our finding that eelgrass makes an important contribution to the food web in Sage Lot Pond is consistent with other stable isotope studies of eelgrass communities in North Carolina (Thayer et al. 1978) and Alaska (McConnaughey \& McRoy 1979), suggesting that use of eelgrass by consumers is common. Stephenson et al. (1986), in contrast, found that eelgrass does not make a significant contribution to consumers in an eelgrass community in Nova Scotia, Canada. Where eelgrass is an important food source, it is probably consumed more as detritus than as live material (Thayer et al. 1975, Zieman 1975). Live eelgrass is less nutritious than algae, but microbially mediated processes during decomposition make it (with associated bacteria) a more favorable food source with time (Tenore et al. 1982).

Childs River: In Childs River, where eelgrass is virtually absent, the stable isotope data show that herbivores and detritus/deposit feeders eat a mix of Gracilaria tikvahiae and Cladophora vagabunda (Fig. 6). Four herbivores (Cymadusa compta, Gammarus mucronatus, Erichsonella filiformis, and Cyprinodon variegatus) fall intermediate between $G$. tikvahiae and $C$. vagabunda in Fig. 6, indicating that they eat similar quantities of the 2 macroalgal species. The herbivore Microdeutopus gryllotalpa falls close to C. vagabunda alone, indicating that it specializes on C. vagabunda. The wider scatter of points for deposit/detritus feeders compared to herbivores in Fig. 6 suggests that the diets of deposit/detritus feeders vary more among species than do the diets of herbivores. It is more likely, however, that variations in $\mathrm{C}$ and $\mathrm{N}$ stable isotope values among deposit/detritus feeders reflect taxon-specific differences in fractionation of $\mathrm{C}$ and $\mathrm{N}$ during assimilation of organic matter (DeNiro \& Epstein 1978, 1981, Minagawa \& Wada 1984), since the species included in the deposit/detritus feeder group belong to 3 different phyla.

The positions of the ribbed mussel Geukensia demissa and the soft-shell clam Mya arenaria in Fig. 6 indicate that these suspension feeders subsist on a mix of phytoplankton and macroalgae Cladophora vagabunda through the consumption of POM in Childs River. As observed for Sage Lot Pond, the ribbed mussel gets a larger proportion of its diet from phytoplankton than does the soft-shell clam.

Secondary consumers. The positions of mummichogs Fundulus heteroclitus, winter flounder Pseudopleuronectes americanus, and the polychaete Podarke obscura in Fig. 8 imply that these organisms feed on benthic fauna. In contrast, sticklebacks Gasterosteus aculeatus and silversides Menidia menidia appear to consume both benthic fauna and zooplankton. We do 
not assign specific organisms to the diets of each secondary consumer because, although the primary consumers we chose for this study are diverse, they represent only a fraction of the species found in Waquoit Bay. Other isotopic investigations of marine food webs also identify organisms that use planktonic and benthic food sources within the same community (Fry \& Parker 1979, Fry et al. 1983, Simenstad \& Wissmar 1985, Peterson et al. 1986, Thomas \& Cahoon 1993, France 1995, Deegan \& Garritt 1997). Deegan \& Garritt (1997) in particular, however, emphasize the mixing of benthic and planktonic food sources in the diets of consumers in estuarine waters. Our stable isotope data on secondary consumers (and also suspension feeders) in the Waquoit Bay estuaries support this perspective.

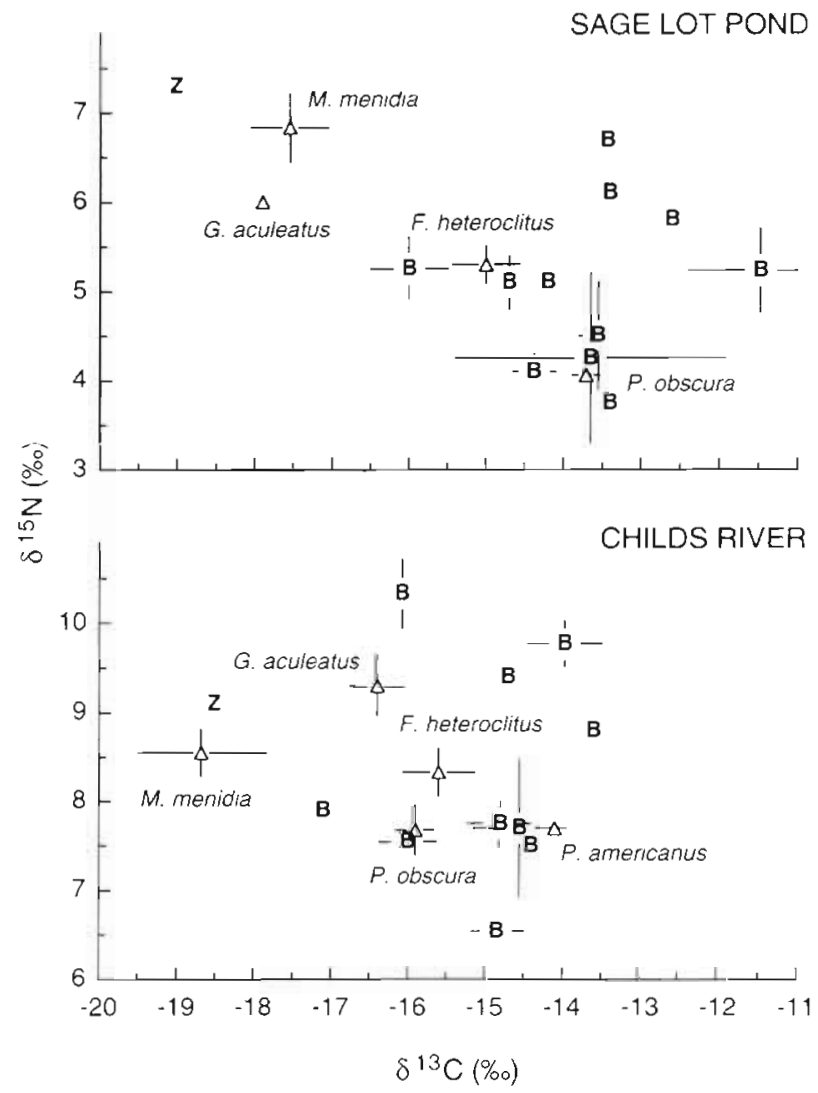

Fig. $8 . \delta^{13} \mathrm{C}$ versus $\delta^{15} \mathrm{~N}$ of secondary consumers (with adjustment for trophic fractionation, see below) compared to $\delta^{13} \mathrm{C}$ versus $\delta^{15} \mathrm{~N}$ of benthic fauna (B) and zooplankton ( $\mathrm{Z}$ ) in Sage Lot Pond (top panel) and Childs River (bottom panel). The stable isotope signature of the ribbed muscle is used as a proxy for that of zooplankton, because its diet is dominated by phytoplankton. Common names for secondary consumers (open triangles) are: silversides, Menidia menidia; stickleback, Gasterosteus aculeatus; mummichog, Fundulus heteroclitus; winter flounder, Pseudopleuronectes americanus; carnivorous polychaete, Podarke obscura. To correct for trophic fractionation, $1 \%$ and $3 \%$ were subtracted from the $\delta^{13} \mathrm{C}$ and

$\delta^{15} \mathrm{~N}$ values respectively of each secondary consumer
Shifts in stable isotope values of secondary consumers from Sage Lot Pond to Childs River (Fig. 8) are difficult to clearly attribute to a loss of eelgrass, since secondary consumers are 2 trophic steps away from eelgrass. Because most of the primary consumers in Sage Lot Pond get a portion of their diet from eelgrass (Table 3), however, it is reasonable to assume that eelgrass carbon and nitrogen are making it into secondary consumers at this estuary.

\section{Conclusions}

Isotopic examination of subtidal food webs in different estuaries of Waquoit Bay shows that diets of primary consumers are influenced by the dominant forms of production that they are exposed to. Phytoplankton and macroalgae are the major food sources of primary consumers under both low and high $\mathrm{N}$ loading conditions, but eelgrass is also an important food source where $N$ loading is low. Seasonal changes in the percentages of eelgrass in the diets of some primary consumers suggest that they feed on live eelgrass or organic aggregates rapidly formed from eelgrass exudates. Other primary consumers have relatively constant contributions by eelgrass to their diets throughout the year, suggesting that they feed on eelgrass detritus stored in the sediments. Felgrass $C$ and $\mathrm{N}$ are passed on to benthic as well as pelagic secondary consumers.

With losses of eelgrass as a result of nitrogen loading, an important pathway through which landderived nitrogen enters food webs in the Waquoit Bay system is eliminated. The ecological implications of this fundamental change have not been defined, but the rate at which land-derived nitrogen is cycled within estuaries, as well as its ultimate fate, must be influenced by the path of nitrogen flow through estuarine food webs. When eelgrass is replaced by algae, it is likely that detrital nitrogen becomes available to estuarine consumers at a faster rate. This is because algal detritus starts out as a nutritious food source to consumers, whereas eelgrass detritus must be microbially altered before it can be used by many consumers (Tenore et al. 1982). As a consequence of faster nutrient cycling, through the detrital pathway, detritivores may become more closely coupled to annual production cycles. Levinton (1972) hypothesized that detritusbased benthic communities are more stable than communities that feed on plankton directly because the food supply to detritus-based communities is relatively constant. Shifts from eelgrass- to algae-dominated production brought about by anthropogenic nitrogen loading may similarly result in less stable communities in shallow estuarine waters. 
Acknowledgements. This work is a result of research sponsored by NOAA National Sea Grant College Program Office, Department of Commerce, under Grant No. NA46RG0470, Woods Hole Oceanographic Institution Sea Grant Project No. R/M-38, and a grant from the NOAA Coastal Oceans Program. The views expressed herein are those of the authors and do not necessarily reflect the views of NOAA or any of its subagencies. We thank B. Peterson and D. Rhoads for their comments on earlier versions of this manuscript. We also thank 3 anonymous reviewers for their kind comments and helpful advice. Stable isotope analysis was done by $\mathrm{R} . \mathrm{H}$. Michener at the Boston University Stable Isotope Laboratory.

\section{LITERATURE CITED}

Alber M, Valiela I (1994) Production of microbial aggregates from macrophyte-derived dissolved organic material. Limnol Oceanogr 39:37-50

Benner R, Fogel ML, Sprague EK, Hodson RE (1987) Depletion of ${ }^{13} \mathrm{C}$ in lignin and its implications for stable carbon isotope studics. Nature $320: 708-710$

Canuel EA, Cloern JE, Ringelberg DB, Guckert JB, Rau GH (1995) Molecular and isotopic tracers used to examine: sources of organic matter and its incorporation into the food web of San Francisco Bay. Limnol Oceanogr 40:67-81

Cebrian I, Duarte CM (1994) The dependence of herbivory on growth rate in natural plant communities. Funct Ecol 8: $518-525$

Costa JE, Howes BL, Giblin AE, Valiela I (1992) Monitoring nitrogen and indicators of nitrogen to support management action in Buzzards Bay. In: Mckenzie DH. Hylact DE, McDonald VJ (eds) Ecological indicators, Vol 1. Elsevier Press, London, p 499-530

Currin CA, Newell SY, Paerl HW (1995) The role of standing dead Spartina alterniflora and benthic microalgae in salt marsh food webs: considerations based on multiple stable isotope analysis. Mar Ecol Prog Ser 121:99-116

D'Avanzo C, Kremer JN, Wainright SC (1996) Ecosystem production and respiration in response to eutrophication in shallow temperate estuaries. Mar Ecol Prog Ser 141 $263-274$

Deegan LA, Garritt RH (1997) Evıdence for spatial variability in estuarine food webs. Mar Ecol Prog Ser 147:31-47

DeNiro MJ, Epstein S (1978) Influence of diet on the distribution of carbon isotopes in animals. Geochim Cosmochim Acta 42:495-506

DeNiro MJ, Epstein S (1981) Influence of diet on the distribution of nitrogen isotopes in animals. Geochim Cosmochim Acta 45:341-351

Duarte CM (1992) Nutrient concentration of aquatic plants: patterns across species. Limnol Oceanogr 37:882-889

Duarte CM (1995) Submerged aquatic vegetation in relation to different nutrient regimes. Ophelia 41:87-112

Fogel ML, Cifuentes LA, Velinsky DJ, Sharp JH (1992) Relationship of carbon availability in estucrine phytoplankton to isotopic composition. Mar Ecol Prog Ser 82:291-300

France RL (1995) Carbon-13 enrichment in benthic compared to planktonic algae: foodweb implications. Mar Ecol Prog Ser 124:307-312

Fry B (1991) Stable isotope diagrams of freshwater food webs. Ecology 72:2293-2297

Fry B. Parker PL (1979) Animal diet in Texas seagrass meadows: $\delta^{13} \mathrm{C}$ evidence for the importance of benthic plants Estuar Coast Shelf Sci 8:499-509

Fry B, Scalan RS, Parker PL $(1983){ }^{13} \mathrm{C} /{ }^{12} \mathrm{C}$ ratios in marine food webs of the Torres Strait, Queensland. Aust $J$ Mar
Freshwat Res 34:707-715

Fry B. Sherr EB (1984) $\delta^{13} \mathrm{C}$ measurements as indicators of carbon flow in marine and freshwater ecosystems. Contrib Mar Sci 27:13-47

Galloway JN, Schlesinger WH, Levy H II, Michaels A, Schnoor JL (1995) Nitrogen fixation: anthropogenic enhancement-environmental response. Global Biogeochem Cycles 9:235-252

Gannes LZ, O'Brien DM, Martínez del Rio C (1997) Stable isotopes in animal ecology: assumptions, caveats, and a call for more laboratory experiments. Erology 78:1271-1276

Gearing JN (1988) The use of stable isotope ratios for tracing the nearshore-offshore exchange of organic matter. In: Jannson BO (ed) Lecture notes on coastal and estuarine studies, coastal offshore ecosystem interactions. SpringerVerlag, Berlın, p 69-101

Gearing JN, Gearing PJ, Rudnick DT, Requejo AG, Hutchins MJ (1984) Isotopic variability of organic carbon in a phytoplankton-based temperate estuary. Geochim Cosmochim Acta 48:1089-1098

GESAMP (1990) The state of the marine environment. Joint Group of Experts on the Scientific Aspects of Marine Pol lution. Rep and Stud 39. United Nations Environmental Programme, Nairobi

Haines EB (1977) The origins of detritus in Georgia salt marsh estuaries. Oikos 29:254-260

Heckscher EI, Hauxwel! I, Jiménez EG, Rietsma C, Valiela I (1996) Selectivity by the herbivorous amphipod Microdeutopus gryllotalpa among five species of macroalgae. Biol Bull (Woods Hole) 191:324-326

Kelly JR, Levin SA (1986) A comparison of aquatic and terrestrial nutrient cycling and production processes in natural ecosystems, with reference to ecological consequences to some waste disposal issues. In: Kullenberg G (ed) The role of oceans as a waste disposal option. NATO Advanced Research Workshop Series. D Reidel Publ Co, Dordrecht, p $165-203$

Lajtha K, Michener RH (1994) Stable isotopes in ecology. Blackwell Scientific Publications, Oxford

Levinton J (1972) Stability and trophic structure in depositfeeding and suspension-feeding communities. Am Nat 106:472-486

Macko SA, Yuh Lee W, Parker PL (1982) Nitrogen and carbon isotope fractionation by two species of marine amphipods: laboratory and field experiments. J Exp Mar Biol Ecol 63: $145-149$

McClelland JW, Valiela I (in press) Linking nitrogen in estuarine producers to land-derived sources. Limnol Oceanogr

McClelland JW, Valiela I, Michener RH (1997) Nitrogen stable isotope signatures in estuarine food webs: a record of increasing urbanization in coastal watersheds. Limnol Oceanogr 42:930-937

McConnaughey T, McRoy CP $(1.979){ }^{13} \mathrm{C}$ label 1 dentifies eelgrass (Zostera marina) carbon in an Alaskan estuarine food web. Mar Biol 53:263-269

Michener RH, Schell DM (1994) Stable isotope ratios as tracers in marine aquatic food webs. In: Lajtha $\mathrm{K}$, Michener $\mathrm{RH}$ (eds) Stable isotopes in ecology and environmental science. Blackwell Scientific Publications, Oxford, p 138-157

Minagawa $M$. Wada E (1984) Stepwise enrichment of ${ }^{15} \mathrm{~N}$ along food chains: further evidence and the relation between $\delta^{15} \mathrm{~N}$ and animal age. Geochim Cosmochim Acta $48: 1135-11.40$

National Research Councll (1994) Prionties for coastal science National. Academy Press, Washington, DC

Nicotri ME (1980) Factors involved in herbivore food preference. J Exp Mar Biol Ecol 42:13-26 
Nixon SW (1986) Nutrients and the productivity of estuarine and coastal marine ecosystems. J Limnol Soc S Afr 12: 43-71

Orth RJ, Moore KA (1983) Chesapeake Bay: an unprecedented decline in submerged aquatic vegetation. Science 222:51-53

Peckol P, Rivers JS (1996) Contribution by macroalgal mats to primary production of a shallow embayment under high and low nitrogen-loading rates. Estuar Coast Shelf Sci 43: $311-325$

Peterson BJ, Fry B (1987) Stable isotopes in ecosystem studies. Annu Rev Ecol Syst 18:293-320

Peterson BJ, Howarth RW, Garritt RH (1985) Multiple stable isotopes used to trace the flow of organic matter in estuarine food webs. Science 227:1361-1363

Peterson BJ, Howarth RW, Garritt RH (1986) Sulfur and carbon isotopes as tracers of salt-marsh organic matter flow. Ecology 67:865-874

Pickett STA (1991) Space for time substitution as an alternative to long-term studies. In: Likens GE (ed) Long-term studies in ecology: approaches and alternatives. SpringerVerlag, New York, p 110-135

Rice DL (1982) The detritus nitrogen problem: new observations and perspectives from organic geochemistry. Mar Ecol Prog Ser 9:153-162

Rice DL, Hanson RB (1984) A kinetic model for detritus nitrogen: role of the associated bacteria in nitrogen accumulation. Bull Mar Sci 35:326-340

Sand-Jensen K, Borum J (1991) Interactions among phytoplankton, periphyton, and macrophytes in temperate freshwaters and estuaries. Aquat Bot 41:137-175

Short FT, Burdick DM (1996) Quantifying eelgrass habitat loss in relation to housing development and nitrogen loading in Waquoit Bay, Massachusetts Estuaries 19:730-739

Simenstad CA, Wissmar RC $(1985) \delta^{13} \mathrm{C}$ evidence of the origins and fates of organic carbon in estuarine and nearshore food webs. Mar Ecol Prog Ser 22:141-152

Stephenson RL, Tan FC, Mann KH (1986) Use of stable carbon isotope ratios to compare plant material and potential consumers in a seagrass bed and a kelp bed in Nova Scotia, Canada. Mar Ecol Prog Ser 30:1-7

Taylor DI, Allanson BR (1995) Organic carbon fluxes be-

Editorial responsibility: Otto Kinne (Editor),

Oldendorf/Luhe, Germany tween a high marsh and estuary, and the inapplicability of the Outwelling Hypothesis. Mar Ecol Prog Ser 120: $263-270$

Tenore KR, Cammen L, Findlay SEG, Phillips N (1982) Perspectives of research on detritus: do factors controlling the availability of detritus to macroconsumers depend on its source? J Mar Res 40:473-490

Thayer GW, Adams SM, LaCroix MW (1975) Structural and functional aspects of a recently established Zostera marina community. In: Cronin LE (ed) Estuarine research, Vol 1 Academic Press, New York, p 518-540

Thayer GW, Parker PL, LaCroix MW, Fry B (1978) The stable carbon isotope ratio of some components of an eelgrass, Zostera marina, bed. Oecologia 35:1-12

Thomas CJ, Cahoon LB (1993) Stable isotope analyses differentiate between different trophic pathways supporting rocky-reef fishes. Mar Ecol Prog Ser 95:19-24

Tomasky G, Valiela I (1995) Nutrient limitation of phytoplankton growth in Waquoit Bay, Massachusetts. Biol Bull (Woods Hole) 189:257-258

Valiela I, Collins G, Kremer J, Lajtha K, Geist M, Seely B, Brawley J, Sham CH (1997b) Nitrogen loading from coastal watersheds to receiving estuaries: new method and application. Ecol Appl. 7:358-380

Valiela I, Foreman $K$, LaMontagne $M$, Hersh D, Costa J, Peckol P, DeMeo-Anderson B, D'Avanzo C, Babione M, Sham C. Brawley J, Lajtha K (1992) Couplings of watersheds and coastal waters: sources and consequences of nutrient enrichment in Waquoit Bay, Massachusetts. Estuaries 15:443-457

Valiela I, McClelland J, Hauxwell J, Behr PJ, Hersh D, Foreman K (1997a) Macroalgal blooms in shallow estuaries; Controls and ecophysiological and ecosystem consequences. Limnol Oceanogr 42:1105-1118

Zieman JC (1975) Quantitative and dynamic aspects of the ecology of turtle grass. Thalassia testudinum. In: Cronin LE (ed) Estuarine research, Vol 1. Academic Press, New York, p 541-562

Zieman JC, Macko SA, Mills L (1984) Role of seagrasses and mangroves in estuarine food webs: temporal and spatial changes in stable isotope composition and amino acid content during decomposition. Bull Mar Sci 33:380-392

Submitted: December 16, 1997; Accepted: April 3, 1998

Proofs received from author(s): June 3,1998 